\title{
Defense Institution Building in Ukraine
}

\section{Leonid I. Polyakov *}

It took over sixteen years - from late 1991, after the collapse of the Soviet Union, to early 2008 (when this article was written) - for an independent Ukraine to make the transition from the virtual absence of national defense institutions to its current defense establishment, which in many respects is already quite close to modern European and Euroatlantic standards. The purpose of this article is to provide a brief overview and generic analysis of how this happened. That is, it will discuss the defense institution building process in Ukraine, a mid-level European power, which in accordance with national legislation and the declarations of the country's leadership aims to join both the European Union and NATO.

\section{Defense Institution Building in Ukraine: Stages of Development}

Stage One: 1991-1996

Chronologically, defense institution building in Ukraine can be divided into three distinctive stages. The first stage, from late 1991 to 1996, can be described as post-Soviet in both form and substance. During this period Ukraine created the main components of the national defense establishment: the Ministry of Defense (MOD) and the General Staff of the Armed Forces (General Staff), along with four branches of the armed services (Army, Navy, Air Force, and Air Defense). All these were basically variations on Soviet military culture with a slight adjustment to the specific national context.

During this period, the major divergences from the model of Soviet military culture took place outside of the MOD, in the newly created structure of the National Security and Defense Council of Ukraine (NSDC), which under the leadership of Volodymyr Gorbulin filled in its own staff with a number of good military professionals, and to some extent within the General Military Inspection under the authority of the President of Ukraine. However, the predominance of uniformed personnel in the Inspection prompted one of the first true military experts (and future Minister of Defense) Dr. Anatoliy Grytsenko to describe it as "civilian control by military means." During this early stage, classic and modern Western doctrines and experiences-such as democratic civilian control over the military, defense resource management in a democratic market-oriented country, joint operations, etc.-were known to some advanced experts and leaders, but they were well understood by almost nobody in Ukraine.

Stage Two: 1997-2004

The second stage of defense institution building in Ukraine lasted from roughly 1997 to 2004, and was evolutionary and declarative. It started when the President of

Leonid Polyakov served as First Deputy Minister of Defense of Ukraine from February 2005 to January 2008.

1 See Anatoliy S. Grytsenko, Civil-Military Relations in Ukraine: System Emerging from Chaos (Groningen: Centre for European Security Studies, 1997), 76. 
Ukraine approved by decree the functions of the MOD and the General Staff, formally introducing the separation of functions between these two bodies. Thus, attempts got under way - mostly declarative in nature - to create something similar to the models that had been adopted in developed democratic countries.

On the positive side, during this period Ukraine proved to be able to develop or amend a number of rather good conceptual and regulatory legislative acts, including the "Concept of National Security of Ukraine," which provided a foundation for Ukraine's national defense policy, and laws "On the National Security and Defense Council of Ukraine," "On Defense of Ukraine," and "On the Armed Forces of Ukraine." Although the drafts of these acts were developed mostly by the personnel of the General Staff, the growing expertise of the NSDC and parliamentary defense staffers allowed them to participate in the creation of meaningful and useful acts as well.

It was also during this stage that the first formal structure responsible for the management of Ukraine's growing Euroatlantic cooperation was created within the General Staff in 1998. It still exists, as a "Directorate of Euroatlantic Integration" within the General Staff, and is located in the same building as the NATO Liaison Office. Over time, the latter office (especially under the leadership of Mr. James Greene) began to play an indispensable role in coordinating all programs of cooperation between Ukraine and NATO, as well as serving in a critical advisory capacity to Ukraine on bilateral discussions with such NATO countries as Bulgaria, Germany, France, Lithuania, Poland, the U.K., and, of course, the United States. Coordination of all foreign advisory activity has become so important over the past decade that in 2007 the decision was made to create an ad hoc Joint Coordination Committee under the leadership of high-level MOD officials.

During this second stage of defense institution building, however, more or less substantive changes in structures and procedures can only be said to have started in 2002, when political leadership made a decision to set a course toward NATO accession. Soon after, in 2003-04, a Strategic Defense Review was conducted for the first time in Ukraine, with the support of NATO International Staff experts.

Among the most visible results at the conclusion of this stage were transformations of the primary MOD directorates, which had been dominated by military personnel, into departments overseen by civilian personnel. Leadership of the MOD became primarily civilian, and a key structure of the civilian MOD - the Department of Policy and Planning — was created.

However, transformations at this stage were mostly structural in nature, both in the MOD (from main directorates to departments) and in the Armed Forces (unification of the Air Force and Air Defense into one service; creation of the Main Directorate of Law and Order Service of the Armed Forces as a loose analog of a military police force, etc.). There still was a significant shortage of qualified civilian personnel to manage MOD functions, and a lack of developed procedures and techniques, especially in the areas of policy development and strategic planning, defense diplomacy, and budgeting and resource management. 


\section{Stage Three: 2005-2007}

In the third stage in the development of defense institutions in Ukraine, which lasted from 2005-07, the victory of democratic pro-NATO candidate Victor Yushchenko and the arrival in the MOD of a new team under the leadership of the Defense Minister Anatoliy Grytsenko, allowed the beginning of systemic transformations. In fact, during 2005, the first year of this stage, the creation of the new Ministry of Defense was completed. The practice of appointing civilians to the office of minister of defense as well as to the deputy minister positions was approved. Since then, all important functions of Ukraine's ministry of defense have generally corresponded to NATO standards for civilian control of the armed forces in terms of guidance and oversight in the areas of policy and planning, personnel and resource management, audit, etc.

However, new structures with new functions required new people, especially for civil service positions. Earlier existing opportunities to train civilian specialists at the National Academy of State Administration (under the Secretariat of the President) and at the National Defense Academy of Ukraine (under the MOD) were unable to produce qualified candidates in sufficient quantity, and were not flexible enough to support the growing needs of the MOD and other security structures.

To help Ukraine's needs, NATO, starting in 2006, began providing funds and training opportunities within an arrangement that became known as the Professional Development Program. Under the supervision of the head of the NATO Liaison Office, the NATO-national Program Manager, and the U.K.'s Special Defense Advisor (representing the lead nation), together with representatives of the relevant Ukrainian authorities, a matrix of requirements was developed and assistance in the selection, training, and placement of civil servants was organized. ${ }^{2}$ As a result, by the end of 2007 Ukraine had satisfied its most immediate needs in training and placing civilian personnel capable of exercising democratic control over the military.

\section{Democratic Control over the Armed Forces}

Transparency. As far as the further development of the overall institution of democratic civilian control over the armed forces is concerned, it has improved its capability to manage not only challenges inside the MOD, but also to communicate with the general public, media, and civil society outside of Ukraine's military establishment. Systems of cooperation with public organizations have been strengthened. A press service within the MOD and the Department of Humanitarian Policy had already been created, which among other responsibilities was tasked with serving as a liaison to local authorities and mass media, managing veterans' affairs, organizing museum exhibitions, and offering family support. In addition to the press office, the Public Council of the MOD was established. It included representatives of all defense, veteran, and patriotic-

2 The Ukrainian representatives to this process included several staff members from the MOD, including representatives of the Department of Personnel Policy's foreign education section and the Department of Policy and Planning's section of European and Euroatlantic integration. 
related non-governmental organizations, which agreed to maintain a regular dialogue with MOD. Since its creation in November 2005, Minister of Defense Anatoliy Grytsenko has personally participated in almost every session of the Public Council, which is made up of about seventy representatives.

Among the other important actions taken by the Ukrainian Ministry of Defense to build transparency and create trust was the introduction of a regularly published "White Book." An annual MOD report to the nation, the "White Book" has become another important element of democratic civilian control in terms of strengthening the military's transparency to Ukrainian society. Since 2005, publication of this report has become an annual tradition, when every year on February 23 (a national holiday, the Day of the Defender of the Motherland), the Minister of Defense, the First Deputy Minister, and the Chief of the General Staff personally conduct a presentation of this publication to the media.

Resource Management. Among the many specific developments in the third stage of defense institution building discussed above, a particularly important place is occupied by the efforts to improve the MOD's resource management system. Until 2005, the funding provided to the Armed Forces was very scarce, if not outright miserly, and drafting the budget proposal was solely the responsibility of the MOD's Department of Finance, together with the General Staff. However, the growth of the Ukrainian economy has allowed defense appropriations to increase, and consequently spurred a demand for better control over resource planning and the spending of taxpayers' money. In addition, growing requirements to satisfy the criteria of NATO accession also necessitated better resource management.

To respond to the changes in these requirements at the "working" level, a special section was established within in the MOD's Department of Policy and Planning that was tasked with oversight over budgeting and overall resource management. At a higher level, but for the same purpose, the Budgetary Commission, headed by the First Deputy Minister of Defense, was created. This board also includes directors of the MOD's Department of Policy and Planning and Department of Finance, as well as key representatives of the General Staff: the First Deputy Chief of the General Staff, the Deputy Chief of the General Staff (in charge of resource oversight), and the Head of J-5 (the Main Directorate of Defense Planning).

In addition to these notable efforts to ensure effective civilian oversight of the MOD's budgetary processes, significant efforts have been made to improve the composition of the defense budget. Experts from MOD's Department of Policy and Planning, the Department of Finance, and department J-5 of the General Staff-utilizing advisory support from Dr. Todor Tagarev, a visiting advisor from Bulgaria — in 2006-

3 Any scholar or practitioner interested in more specific details of defense institution building in Ukraine in the period of 2005-07 will certainly benefit from reading more specific texts of the relevant White Books $(2005,2006,2007)$, which can be found in English at the Ukrainian MOD website at www.mil.gov.ua. 
07 worked hard to ensure direct, well calculated, and clearly understood linkages between the anticipated end results of each defense program, its cost and efficiency. ${ }^{4}$

In parallel to the efforts mentioned above, another project was under way aimed at making all administrative processes in the MOD and the Armed Forces more effective by introducing an automated system of control over administrative processes. ${ }^{5}$ To facilitate this process, a specific structure was created within the MOD, a Directorate of Information Resources. In addition, in order to more effectively manage the consequences of the Ukrainian military's significant downsizing and transformation, two distinct structures were created within the MOD: the State Department for Adaptation of Retired Personnel and Conversion; and the State Department of Surplus Materiel and Lands.

Command and Control. The final achievement during the third stage of the defense institution building process in Ukraine was a significant improvement in the systems of command and control of the Armed Forces. First of all, the operational chain of command underwent modernization. A Joint Operational Command assumed the operational responsibilities of three former territorial operational commands. Three territorial directorates assumed responsibility for territorial defense and administration of mobilization and reserves in their respective areas of responsibility. Three Army Corps were removed from the control of the territorial operational commands and placed under direct control of the Army Command. A new command structure- the Command of Special Operations Forces - was created at the branch level in response to changes in the threat environment. And the General Staff was restructured in accordance with standards adopted in the headquarters of NATO militaries.

\section{Conclusion}

In conclusion, the next stage after the third will start in 2008, should Ukraine become a participant in the Membership Action Plan, for which the nation's leadership applied in January 2008. It is likely that this new stage will be characterized by the attrition of structures dedicated to dealing with excess equipment and ammunition and with other consequences of military downsizing. Further strengthening of the structures, staffing models, and procedures related to "strictly" democratic civilian control will probably take place as well. Some integration of MOD and General Staff structures will also likely take place in cases where joint civilian-military components are considered to be more effective than functions that are separated between the civilian MOD and the military General Staff. More specific details will likely become clear after the completion of the next Strategic Defense Review, which is planned for 2008-09.

Overall, despite a slow start, significant progress in defense institution building in Ukraine is evident. The country's course toward building democracy and integrating

4 See for details the article Todor Tagarev, "Introduction to Program-Based Defence Resource Management," Connections: The Quarterly Journal 5:1 (Spring-Summer 2006): 55-69, published also in Ukrainian in Nauka i Oborona 3 (2006): 18-24.

5 Using SAP software. 
more closely with NATO and the EU, along with its close security cooperation with the Western democracies, has provided opportunities for Ukraine to educate its military and civilian personnel and to gain valuable foreign experience and practical support, which has made a noticeable difference in the process of defense institution building. This cooperation has also encouraged the construction of a functioning system of democratic control over the military, as well as the development of institutions and procedures of policy, planning, and resource management in the MOD, and improved effectiveness of command and control systems in the Armed Forces. 
SUMMER 2008

\section{Bibliography}

Grytsenko, Anatoliy S.. Civil-Military Relations in Ukraine: System Emerging from Chaos . Groningen: Centre for European Security Studies, 1997.

Tagarev, Todor. "Introduction to Program-based Defense Resource Management." Connections: The Quarterly Journal 5, no. 1 (2006): 55-69. 